\title{
9 \\ Urban Land Grabbing by Political Elites: Exploring the Political Economy of Land and the Challenges of Regulation
}

Siobhan McDonnell

\section{Introduction}

Internationally there is a large and growing body of scholarly literature that describes problems of 'land grabs' whereby local actors, including indigenous people, lose access to land. This international land grab literature overwhelmingly focuses on large-scale land transformationon a new scale and with a new intensity-resulting from processes of globalisation, the liberalisation of land markets, and increases in foreign direct investment in land (Deininger 2003; Sikor and Müller 2009; Borras and Franco 2010; Zoomers 2010: 130; Li 2014). In this literature, land is grabbed not only by high-wealth individuals but also by foreign governments demanding a supply of cheap food crops or arable land on which to grow biofuels and non-food agricultural crops (Cotula et al. 2008, 2009; Borras and Franco 2010; Zoomers 2010). Development of nature reserves and conversation areas form another basis for largescale land transformation (Peluso and Lund 2011; Peluso 2012). The suggested overall trend from land grabbing is a shift in landownership from indigenous people to foreigners (Zoomers 2010: 440). In the work 
of Derek Hall, Philip Hirsch and Tania Murray Li (2011), this land grabbing is described in terms of the processes of exclusion of people from landscapes.

In contrast with much of this global literature, this chapter seeks to focus on the way in which political elites across Melanesia are instrumentally involved in land transformations, and particularly in the leasing of commercially valuable urban state land. In Vanuatu, state land is defined in Section 9 of the Land Reform Act as public land belonging to the colonial state powers that was vested in the Republic of Vanuatu on the day of national independence. ${ }^{1}$ Urban state land is an important site for illustrating the exercise of state power, and in particular for considering in whose interests state actors transact public land. This chapter uses the term 'land grab' in an instrumental way to describe the agency of state actors who lease urban state land without regard to the public interest. Here the act is one of political elites seizing land and leasing it in their own self-interest in defiance of the rule of law or administrative requirements. Hall, Hirsch and Li describe these processes as 'licensed exclusion', whereby governments award legal titles to some people rather than others (Hall et al. 2011: 27). This chapter will explore the idea of licensed exclusion and the broader processes of regulation with reference to a case study of ministerial leasing of urban state land in Vanuatu.

Hall, Hirsch and Li view regulation as a set of rule-backed claims over a particular area of land, where rules over land establish boundaries, types of land use, ownership and zoning requirements (Hall et al. 2011: 15-16). While processes of exclusion are informed in significant ways by particular legal contexts, the importance of formal rules can be exaggerated. In this chapter, I argue that the exercise of state power over land is guided by: (1) the operation of the shadow state; (2) the behavioural norms established by political elites in transacting state land; (3) the operation

1 According to Section 9 of the Act:

(1) On the Day of Independence all state land shall vest in the Government and be public land and be held by it for the benefit of the Republic of Vanuatu.

(2) The Minister, on the advice of the Council of Ministers, may by Order declare that any land described in the Order ceases to be public land.

(3) In accordance with Article 81 of the Constitution the Minister may, on the advice of the Council of Ministers, by Order vest any public land in indigenous citizens or communities referred to in the Order for such payment by them and on such terms and conditions as may be referred to in the Order.

(4) When an Order is made under subsection (3) it shall provide for payment of compensation to the custom owners by the Government and the amount of such compensation shall be set out in the Order. 
of property law; and (4) the organisational 'culture of complicity' in land administration agencies. Rather than enhancing formal rules, these processes can work to establish behavioural norms that often defy the legal frameworks established with respect to land dealings.

\section{Land Transformation in Melanesia}

In discussing land transformations in Melanesia, important distinctions need to be made about the scope of customary landholdings and the ambit of states in Southeast Asia-the context that informs the work of Hall, Hirsch and $\mathrm{Li}$-when compared with Melanesia. In Melanesia, the overwhelming majority of land is held under customary tenure arrangements, although both Papua New Guinea (PNG) and Vanuatu have experienced 'land grabs' over customary land in recent years. Written to engage with the broader international debate around land grabbing, Colin Filer's work details the large-scale leasing of customary land in PNG through the grant of 'special agricultural and business leases'. Filer meticulously details the more than five million hectares of customary land (11 per cent of PNG's total land area) 'grabbed' by private companies between 2003 and 2011, while at the same time challenging much of the central 'land grab' narrative in the process (Filer 2011,2012; also Chapter 6 , this volume). In a similar vein, my work documents the processes by which, over the last 15 years, Vanuatu has experienced a dramatic land grab, with more than 10 per cent of all customary land now leased (McDonnell 2016). On Efate Island alone, 56.5 per cent of what was previously held as customary land along the coastline is now leased (Scott et al. 2012: 4; see Figure 9.1). This has the effect of limiting Ni-Vanuatu access to both the most arable land and much of the coastal estate.

In Melanesia, the geographical scope of state authority is more constrained than in Southeast Asia. While formal state law guides the market in land in Melanesia, many local disputes are managed through customary institutions. Land use access and exclusion is often dictated by customary rules enforced by local male leaders in what is described in the introduction to this volume as 'the neo-traditional social order'. Across Melanesia, male leaders, increasingly termed 'chiefs', engage in acts of 'intimate exclusion', validating their own claims of authority over land to the exclusion of the broader landowning group, especially women and young people (Hall et al. 2011: 145; see also Chapter 1, this volume). I call these men 'masters 
of modernity', rather than 'masters of tradition' (Rodman 1987), because of the way that they have used the power of the state, as well as their claims to customary authority, in attempts to legitimate their dealings with foreign or non-indigenous real estate developers (McDonnell 2013, 2016).

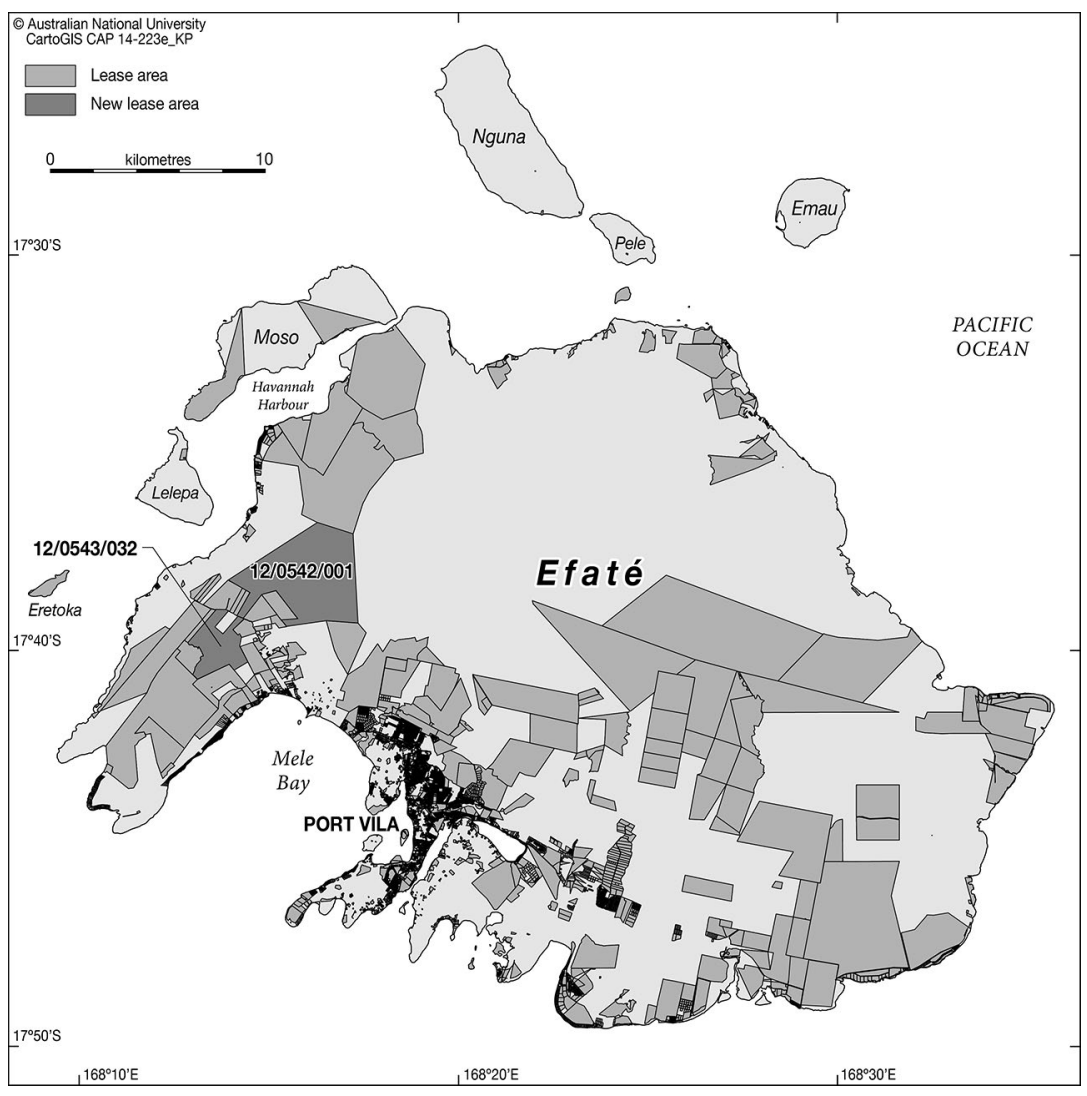

Figure 9.1 Leases on Efate Island as at 2015.

Source: CartoGIS, The Australian National University, based on data provided by the Vanuatu Ministry of Lands.

Note: National lease data indicate that 46 per cent of the Efate land mass is leased, but this statistic was compiled before the leasing of two large areas of customary land in north Efate (titles 12/0543/032 and 12/0542/001).

In spite of some constitutional similarities, the regulatory arrangements over land vary substantially across Melanesia. However, while the rules differ, there are commonalities across the region in how political elites and government officials work to facilitate land transactions, as well as logging deals and mining arrangements, for their own benefit or for the benefit of corporate or individual investor interests. 
Hall, Hirsch and $\mathrm{Li}$ use the term 'licensed exclusion' to refer to the process by which the state licenses access to land, through a legal title, to some people, while at the same time excluding others (Hall et al. 2011: 27). Licensed exclusion is described through an exploration of land formalisation and land titling projects in Southeast Asia whereby the state makes land 'legible' through surveying, creating categories of ownership, allocating land titles, ultimately allowing for the commodification of land (Scott 1998; Hall et al. 2011: 27-9). The Australian company that has been at the forefront of land registration in several South East Asian countries, Land Equity International (LEI), also operated the Australian government's land program in Vanuatu. Land titling programs based on Torrens Title registration were rolled out through Thailand, Laos, Indonesia and the Philippines (Hall et al. 2011: 35). More recently, LEI has played a lead role in Vanuatu's five-year Land Program, at a cost of AU $\$ 23$ million, which has been focused on improving the administration of land by government agencies and on the registration of all outstanding leasehold titles. However, these efforts at improving land administration have done little to address what I shall call the 'culture of complicity', which involved the Minister for Lands gifting state land to government officers. ${ }^{2}$

\section{The Impact of the Shadow State on Regulation}

Melanesian states are embedded in political economies largely dominated by the exploitation of natural resources associated with mining, forestry, and land itself. These political economies mean that Melanesian states are situated in webs of patronage_-global and local—such that political alliances with investors representing transnational institutions inform the exercise of state power. These shifting political networks form the shadow state that operates behind the façade of the formal state, beyond the ambit of written laws and institutional processes (Reno 2000: 434). It is these networks of the shadow state that often guide the operation of state power over customary and state land in Melanesia. Shadow state networks also

2 The Australian government and other donors must be cautious of a programmatic approach that creates silos of expertise in which some staff become essential to the land administration process. Where this occurs, it tends to create an opportunity for staff to broker their own individual payments as part of the government land administration process. For example, if only a single staff member can operate a system designed to create maps, then this staff member may demand additional direct compensation for this skill set. 
dominate ministerial leasing of urban state land, and across Melanesia, development, planning and environmental regulation is regularly subverted through the alliances of investors with politicians.

Political elites do not always perform land transactions in accordance with the rules written in national constitutions, laws and regulations. Licensed exclusion does not describe the processes by which specific state actors are included in this type of performance. The dominance of the shadow state means that, across Melanesia, state actors offer concessional access to land to their investor partners or close business and political associates. Politicians also routinely allocate valuable urban state land to members of their immediate family or wider kinship networks. These acts of licensed inclusion affect the access for other rights holders and override public interest or rule of law requirements. In Vanuatu, successive lands ministers have repeatedly acted in contravention of the law by leasing urban state and customary land for their own benefit, or in the interests of investors. Court and Ombudsman decisions detail numerous acts of licensed inclusion: ministers granting land to themselves, close family members, kin, or 'wantoks', as well as political associates and close business associates. ${ }^{3}$ For example, the Ombudsman's decision in relation to former Minister for Lands Paul Telukluk found that ' 15 land titles were improperly allocated by the Former Minister for Lands ... to himself, Members of his Family and wantoks (people of his island community)'. ${ }^{4}$ These judgements demonstrate that successive lands ministers have regularly leased urban state land in acts of intimate inclusion to immediate family members and kin.

3 Public Report on the Conduct of Messrs Vohor, Dope and Boulekone Regarding an Attempt to Contract with Volani International Ltd [1998] VUOM 4; Public Report on the Improper Sale of Government Houses by the Office of the Prime Minister under the former Prime Minister Maxime Carlot Korman [1998] VUOM 7; Public Report on the Improper Granting of Land Lease Title 11/0E22/016 by the Former Minister Paul Telukluk and Former Director of Lands Roger Tary. [1998] VUOM 10; Public Report on the Granting of Leases by the Former Minister for Lands Mr Paul Barthelemy Telukluk to Himself, Family Members and Wantoks. [1999] VUOM 6; Public Report on the Mismanagement of the Tender Sale of the Ten (10) Deportees' Properties by the Former Minister of Lands, Mr Paul Telukluk. [1999] VUOM 9; Public Report on the Improper Conduct by Public Officials in Dealing with Mondragon's Proposed Free Trade Zone in Big Bay, Santo [2001] VUOM 3. See also Ifira Trustees Ltd $v$ Kalsakau [2007] VUSC 119.

$4 \quad$ Public Report on the Mismanagement of the Tender Sale of the Ten (10) Deportees' Properties by the Former Minister of Lands, Mr Paul Telukluk. [1999] VUOM 9. 


\section{Legitimation of State Power over Land}

According to Hall, Hirsch and $\mathrm{Li}$, legitimation of state power is the cornerstone of regulation. Legitimation as a process of exclusion 'establishes the moral basis for exclusive claims, and indeed for entrenching regulation ... as politically and socially acceptable bases for exclusion' (Hall et al. 2011: 5, 19). Rather than a moral or acceptable basis, legitimation must be understood as central to establishing regulatory authority. Nancy Peluso and Christian Lund describe regulatory processes through the lens of 'legalisation'-the process of defining ownership through claims to property rights. Through legalisation and the associated 'legal titles', certain claims are legitimised, and when enforced, turn previous rights holders into 'poachers and squatters' (Peluso and Lund 2011: 674). Formal rules retain significance because they are the means of 'laundering power' by claiming legitimate authority over land.

Across Melanesia, formal rules are often used erroneously to justify the exercise of state power over land, even where these acts of power are beyond the actual text of the rules. However, establishing legitimate state authority over land can occur almost regardless of the formal rules. In Vanuatu, there are two specific processes that have resulted in the state retaining authority over urban and customary land, even where the land was leased in dubious legal circumstances: (1) the establishment of new behavioural norms, and (2) the tenets of property law.

The behaviour of state actors influences the informal rules that govern land dealings. Governmentality is the 'conduct of conduct' - the attempt to shape the behaviour of citizens by distinctive means so as to create a 'governmental rationality' (Foucault 1991: 93-5). Acts of leasing state land work to establish the governmentality of land by the state, even where this is beyond the formal rules. Where regulatory processes are undertaken by key state actors, they become the embodied practices of governmentality.

In Vanuatu, lands ministers have repeatedly leased state land in breach of the criminal code and the leadership code..$^{5}$ The leadership code enshrined in the national constitution specifically requires that members of parliament and government officials do not use their office for 'personal gain or enter

5 PNG, Solomon Islands and Vanuatu all have leadership codes in their constitutions that mandate codes of behaviour for politicians and public servants. 
into any transaction or engage in any enterprise or activity that might be expected to give rise to doubt in the public mind'. ${ }^{6}$ Ministerial leasing of customary and urban state land is legitimated by the failure to prosecute any illegal acts. This failure to prosecute lends an obdurate legitimacy to acts of state power over land.

A minister transacting land with the authority of the state changes the way that the processes of legitimation occur. The behaviour of key actors can comply with, or circumvent, the law (Lund 2009: 139). This is because the legitimation of state power over land involves more than rules:

what is perceived as legal or illegal may change over time without any change to legislation. Government policies, statements and practices can effectively outlaw certain legal practices and nullify certain established rights (Sikor and Lund 2009: 7; see also Lund 2009).

The Vanuatu example demonstrates that acts of successive lands ministers in leasing state land have operated to nullify established public rights over land without substantial changes to the law as written.

\section{The Register is Everything}

The legitimation of state power over land is also established by property law. The effect of property law operates to override the circumstances by which state land transactions occur. The legal foundation of formal property rights in Melanesia is Torrens Title indefeasibility: once a lease is registered it is unable to be broken. The grounds for challenging the registration of a lease are very limited, ensuring the stability of the titling process. By giving effect to registration, the power of the state over land is made legitimate. Property rights in natural resources are 'intimately bound up with the exercise of power and authority' (Sikor and Lund 2009: 1). The acts of lands ministers in Vanuatu provide an illustration

6 According to Article 66 of the Constitution:

(1) Any person defined as a leader in Article 67 has a duty to conduct himself in such a way, both in his public and private life, so as not to - (a) place himself in a position in which he has or could have a conflict of interests or in which the fair exercise of his public or official duties might be compromised; (b) demean his office or position; (c) allow his integrity to be called into question; or (d) endanger or diminish respect for and confidence in the integrity of the Government of the Republic of Vanuatu.

(2) In particular, a leader shall not use his office for personal gain or enter into any transaction or engage in any enterprise or activity that might be expected to give rise to doubt in the public mind as to whether he is carrying out or has carried out the duty imposed by subarticle (1). 
of the argument that recognition of property works to legitimise the authority of the institution making the determination. Leases allocated by the Minister, even where this is beyond his legal powers, have been legitimated by the operation of the tenets of property law. Once leased by a minister and registered, a lease title over state land becomes indefeasible.

The power of the Minister to create property rights has been repeatedly upheld by the courts in Vanuatu, based on their interpretation of the legislation that governs lease making. Courts in Vanuatu have repeatedly stated that:

The essential feature of any Torrens System is the indefeasibility of the title of the registered proprietor ... the effect of all these provisions is that the register is everything. The title of the registered proprietor ... is protected against any adverse claims or interests not entered in the register except as provided in the Act. ${ }^{7}$

Property interests are detailed in the register, and the register is everything. Once the technical requirements of the property transaction and registration are met, the transaction is likely to be held to be indefeasible. Torrens Title registration creates a repository of interests in land so as to 'protect persons dealing in registered interests in land' regardless of the circumstances in or the consideration for which such proprietor or any previous proprietor was registered'. ${ }^{8}$ The property rights of the titleholder of the registered instrument are backed by the implicit force of the state, thereby excluding prior claims of other groups. The position of the lands minister is legitimated by the power to create property rights, which has been upheld by the courts and backed by the authority of the state. This in turn legitimates the authority of the minister as the state actor who transacts land.

\section{The Organisational Culture of Complicity}

Land administration agencies across Melanesia demonstrate a widespread culture of complicity whereby many government officers either support political elites who engage in illicit acts, or themselves facilitate property transactions on the basis of illicit payments. This culture may operate in part because government officers fear for their jobs or face persecution

7 Toro v Kiri [2013] VUSC 210. Paragraph 8 (emphasis added).

8 See Section 23 of the Land Leases Act. 
if they do not comply with directions from their political masters. But it is also clear that some government officers promote illegal acts by key state actors for their own personal gain.

A number of systemic problems with land administration have been identified across the Melanesian region, namely that land administration officials may collude with outside investors to: tamper with or destroy land records; lower valuations of state land so that they do not reflect the market value and to reduce taxes payable; lower land prices or give preferential access to state land to certain investors or politicians; and regularly circumvent planning and environmental processes. However, this does not mean that all officers involved in land administration are inveigled by an organisational culture of complicity.

\section{Minister Kalsakau's Grabbing of Urban State Land}

The laundering of state power over land by political elites and the culture of complicity in place in land administration are best understood with reference to a case study from Vanuatu. In 2012, at least 190 leases over state land were approved by the former Minister for Lands Steven Kalsakau to individuals in three general categories: (1) government officers comprising staff from the Department of Lands, the Ministry of Lands, and other related government agencies (including those responsible for agriculture, environment, planning and valuation); (2) Kalsakau's personal business and political associates, comprising his close circle of political advisers and personal staff; and (3) close family members, including his son Periaso Kalsakau, who as a child should not legally have been able to hold a lease interest (GoV 2014: 39). ${ }^{9}$ Minister Kalsakau's grants of urban state land leases to his business and political associates, and to close family members, illustrate the processes of regulatory inclusion. For example, the Minister's political associates included his close circle of political advisers and staff members, including his personal driver.

In an illustration of the widespread culture of complicity, leases over valuable urban state land were granted to all 40 staff in the Department of Lands and Ministry of Lands, from senior management to office cleaners. In some instances staff received single leases, but particularly well-connected staff received four or five parcels of state land,

9 For this reason, when Ralph Regenvanu became Minister for Lands, he was able to cancel this lease. 
or arranged for their wives, sons or close relatives to also be granted leases (GoV 2014: 21). Significantly, 11 staff who were granted leases did not subsequently register their leases over state land (ibid.: 9).

A Public Service Commission investigation into the Kalsakau leases describes the challenges faced by the investigation team as all senior staff, and around '80 per cent' of all other Lands Department staff, were implicated in the granting of state land leases (GoV 2014: 41). ${ }^{10}$ The entrenched, widespread culture meant that senior government officers felt confident in requesting that the Minister offer them concessional leases over state land. This request was responded to on 3 August 2012 when Minister Kalsakau issued a letter to the Acting Director of Lands:

A lot of staff members have approached me and sincerely requested that they wish to acquire and obtain leaseholds either in Vila or Luganville state lands.

Please find out available plots and allocate each of those staff that has sufficient funds to pay relative fees for the land on the following negotiable arrangement:

1. Pay only $50 \%$ of the premium, deposit $10 \%$ of the said amount and register the lease and let them organize settlement with the Banks.

2. Must pay full value of all administration fees

3. The lease term to run for fifty (50) years

4. The registered lease would be a non-transferable instrument until the premium balance is fully paid.

5. Type of lease should be classed according to the appropriate zoning and location.

I would expect that you organise this as a priority and forward all certificates and leases to me for approval (Kalsakau 2012).

10 A key recommendation of the team's report was that the Public Service Commission: 'formally question the former DG [Director General] of MOLNR [Ministry of Lands and Natural Resources] and the Acting Director at that time, Mr. Peter Pata, as to why they didn't ensure that the officer[s] of the MOLNR and the DOL [Director of Lands] have followed the ... [proper] processes ... After all, it is the view of the [investigating team] that if the former DG and the Acting Director have properly monitored the processes of lease application and registration done by their officers, they (i.e. the former DG and Acting Director) would have detected the flaws in the process and would have addressed them appropriately' (GoV 2014: 38-9). 
Following from this letter, on 4 October 2012, the Land Management Planning Committee (LMPC), staffed by senior Lands Department staff and representatives of other government agencies, approved the registration of the leases. ${ }^{11}$ The 10 -member committee approved the allocation of leases to themselves and to other staff, thereby breaching the leadership code and requirements under the Public Service Act that government staff do not personally benefit from their positions. ${ }^{12}$

The Kalsakau leases were issued without any regard to existing planning and environmental regulations for the Port Vila and Luganville areas. Leases were issued over many of the remaining public spaces and areas of natural parkland in Port Vila and Luganville. A number of leased areas contain cultural sites such as old nasara (dancing) grounds, and trees registered as sites of national heritage by the Vanuatu National Cultural Council. ${ }^{13}$

The Kalsakau leases included numerous leases over commercially valuable real estate with high market value. In Port Vila, leases were issued in Tassariki-the wealthiest residential area-and over part of a luxury resort. Leases were also issued over the site of the former Joint Court House, prime real estate with views across the harbour. Together, the Kalsakau leases involved significant grants of valuable commercial urban state land. The amount of state land leased in Port Vila and Luganville was 128,288 square metres and 67,205 square metres, respectively. The total value of state land leased in Port Vila was approximately VT781,818,000 (approximately AU $\$ 8$ million) and that of the leases in Luganville was VT181,054,000 (AU\$2 million). In numerous instances, the leases also included existing government properties, roads and infrastructure, including existing police housing. In a complete abrogation of government

11 The staff in the LMPC meeting who allocated themselves land were Peta Pata (Acting Director of Lands and chair of the LMPC), Joe Keilson (Lands Department Planning Section and secretary of the LMPC), Phillip Koroka (Lands Department Survey Section), Benuel Tabi (Lands Department Land Lease Section), Gwen Wells (Lands Department Registration Enforcement Officer), Prosper Buletare and Anaclet Philip (Sanma Province representative), Harry Tete (from Luganville Municipality), Philip Banban (from the Department of Agriculture), and Dick Tomker (from the Forestry Department) (GoV 2014: 13).

12 The recipients were mainly located within the Ministry of Lands and Department of Lands but also included representatives from the Environment Office, municipal agencies, and the Department of Geology and Mining (GoV 2012).

13 Preservation of Sites and Artefacts (Amendment) Act 2008. 
processes, leases were offered to staff without any consideration of their market value or the value of the state properties and assets located on many of them. ${ }^{14}$

Examples of the leases in Port Vila are shown in Figures 9.2, 9.3 and 9.4. The first example, near Independence Park (Figure 9.2), is a lease that was granted to Masoi John Alexine, an associate of Steven Kalsakau. The property was subsequently valued at VT19,500,000. The second example (Figure 9.3) comprises leases issued behind the Malvatumauri chief's nakamal in an area adjacent to Seaside. The third example (Figure 9.4) is a lease that the Minister issued to his own son, covering commercially valuable land located in Tassariki, next to the New Zealand High Commissioner's residence.

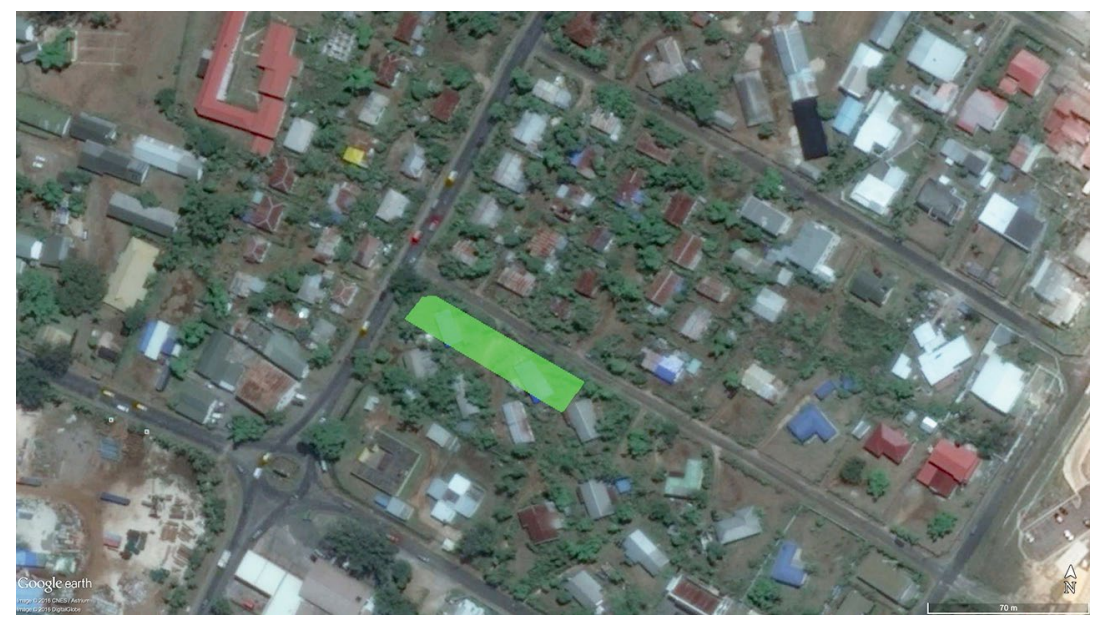

Figure 9.2 Lease titles allocated to staff over state land leased near Independence Park, including two houses.

Source: Author's rendition of Google Earth imagery, overlaid by data obtained from the Vanuatu Ministry of Lands.

14 The public interest requirement associated with the leasing of state land and state assets should have at least ensured that the process involved the competitive tendering for land and assets greater than VT5 million, in accordance with the legal requirements of the Financial Services Act. 


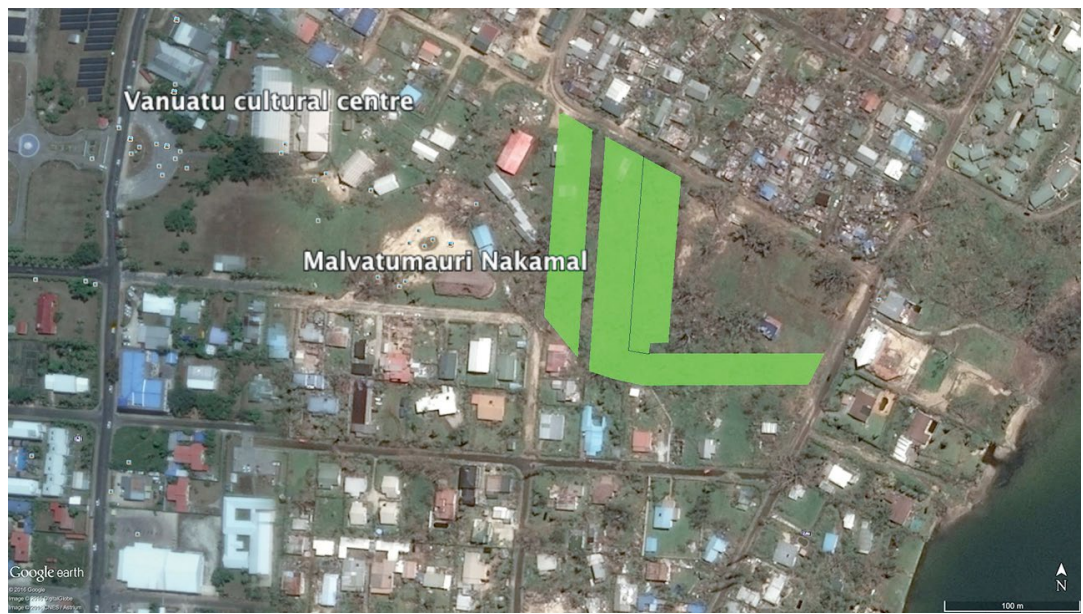

Figure 9.3 Lease titles allocated to staff over parkland, existing Nasara areas and cultural sites adjacent to Seaside show ground.

Source: Author's rendition of Google Earth imagery, overlaid by data obtained from the Vanuatu Ministry of Lands.

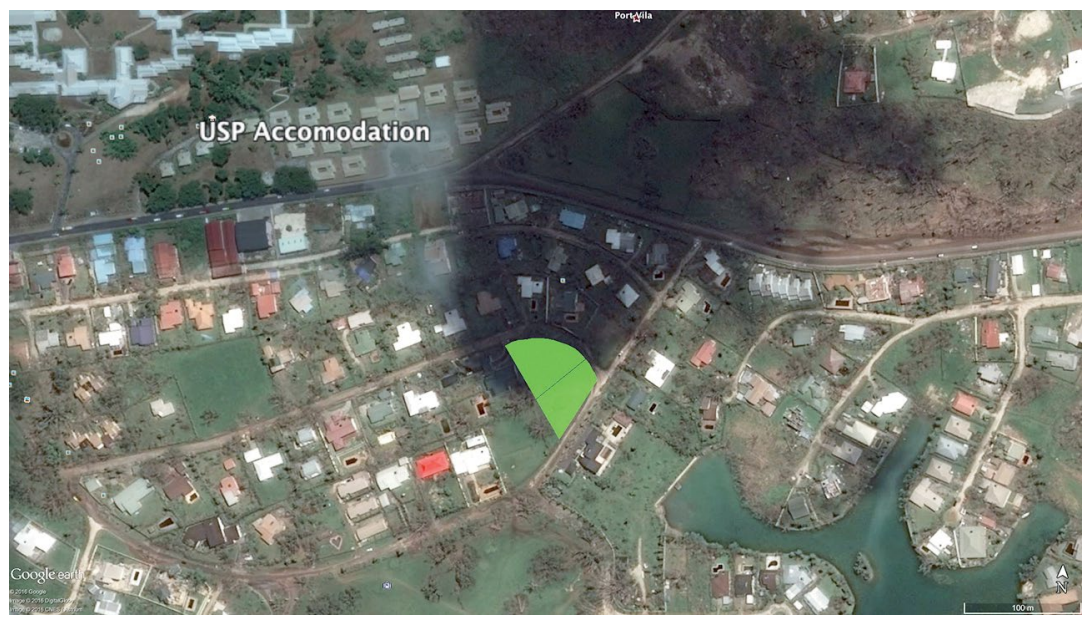

Figure 9.4 Lease title issued by Minister Steven Kalsakau to his son Periaso Kalsakau.

Source: Author's rendition of Google Earth imagery, overlaid by data obtained from the Vanuatu Ministry of Lands. 
Like many other ministerial leases over state land, the Kalsakau leases resulted in a loss of substantial revenue to the state. Most government officers paid premiums of less than 1 per cent of the value of the land, with at least four staff making no payments at all for their leases. ${ }^{15}$ For example, government surveyor Harold Moli registered a lease title over part of the grounds of a luxury hotel without paying any premium for the lease or any administrative fees. While Moli paid nothing, the land was subsequently independently valued at VT8,340,000 (just under AU\$100,000) (GoV 2014: 34). These amounts suggest the scale of the illicit financial gains made by government officers who support lands ministers in their gifting of urban land, and who maintain an organisational culture of complicity.

\section{In Defence of the Culture of Complicity}

Minister Kalsakau's issuing of leases involved him in an orchestrated bypassing of proper legal and administrative processes that was supported by government officers. ${ }^{16}$ In March 2013, Ralph Regenvanu became Minister for Lands and I was appointed as his legal adviser. The new Ministry of Lands team convened a meeting of all government officers involved in Kalsakau's scheme to request that that those who had obtained

15 A report prepared by the Valuer-General for the Public Service Commission suggests that all titles were undervalued, premiums were assessed incorrectly based on this undervaluation, some premiums were assessed on a 50-year lease term when the term of the lease was 75 years, and some leases had no valuations done at all (GoV 2014: 35). The grant of leases to staff as gifts is inconsistent with Section 100 of the Land Leases Act, which requires that land be leased for a 'valuable consideration'. It is arguable that this requirement could be used as a basis to cancel the lease instruments where no actual payment was received or-as in the overwhelming majority of leases - where the payment received amounted to less than 1 per cent of the independent valuation of the land. It is likely that similar or greater concessions were offered to the business and political associates of Minister Kalsakau, but statistics related to these land grants are not currently available.

16 Proper administrative process was not followed in the allocation of leases to staff: very few staff actually complied with the ministerial instruction in terms of the amount to be paid; no staff applied for leases over state land following the usual application process; many staff did not pay all of the administrative and registration fees prior to registration-something that in usual circumstances would mean that the lease could not be registered. Administratively, each lease instrument that is submitted for registration should include a 'checklist' to ensure legal and administrative compliance with the requirements of various agencies (State Law Office, Planning Department, Environment Department, and Lands Department). In practice, like the Kalsakau leases, leases are routinely registered in Vanuatu without any reference to this checklist, and with little more than the consenting signature of the minister. 
leases 'through flawed processes' surrender them. ${ }^{17}$ This request was made in the context of pending court cases and investigations by the Public Service Commission and the Ombudsman.

Standing before a room full of staff in a meeting convened in the Malvatumauri Nakamal (see Figure 9.3), the Minister, lawyers from the State Law Office, members of the Public Service Commission investigation team and I all asked the government officers to surrender their leases. Senior government staff who had orchestrated the arrangement responded with indignation to this request. In the days following the meeting, only one staff member took action to surrender their lease. During the initial meeting and in subsequent discussions, the government officers repeatedly defended the leases on the grounds that the authority of the Minister to consent to the transactions is legitimated by the state, and that this overrides any other legal or process requirements. ${ }^{18}$ These arguments were repeated by staff during Public Service Commission interviews where they stated that 'the Minister as Lessor had an agreement with them as Lessee. Thus, according to them [the staff interviewed] when the Lessor gave them the authority to proceed in registering the land, it is a legal instruction' (GoV 2014: 21). Using their expert knowledge of the law, government officers argued that the leases had been consented to by the Minister and subsequently registered, and were now 'indefeasible' property rights that could only be challenged through the courts. ${ }^{19}$

17 The meeting was chaired by the Acting Director-General of the Ministry of Lands and was attended by the Chairman of the Public Service Commission, the Public Service Commission investigating team, staff of the Office of the Ombudsman, legal representatives from the Office of the Attorney-General, and the legal adviser to the Minister for Lands. Each staff member was individually handed a letter signed by the Minister that stated, in part: 'I write to you in my capacity as the Minister for Lands requesting that you surrender the lease or leases issued to you over state land by the former Minister for Lands Steven Kalsakau. As you are aware there is currently a court case and two internal investigations being undertaken to identify the current and previous staff of the Department of Lands and Ministry of Lands who have obtained leases in the last 12 months ... The powers of these Public Service Commission and Ombudsman investigations are broad and far reaching. While I await the findings of the inquiries it is highly likely that staff who have been involved in obtaining leases through this process may be subject to disciplinary proceedings and/or prosecution under the Penal Code [CAP 135] and under the provisions of the Leadership Code [CAP 240]. Accordingly I wish to provide staff with an opportunity to surrender the leases that they have obtained over state land through these flawed processes.'

18 The Public Services Act makes clear the duties of all government employees which include: to disclose and take reasonable steps to avoid any conflict of interest (real or apparent) in connection with his or her employment; to use resources and public money in a lawful and proper manner; and not to make improper use of information or use his or her duty, status, power or authority in order to gain or seek to gain a benefit or advantage for himself or herself or for any other person.

19 The usual legal grounds for challenging existing leases are contained in Section 100 of the Land Leases Act. 
Government officers also repeatedly referenced previous staff-facilitated leasing of urban state land by other former lands ministers, including Paul Telukluk and Maxime Carlot Korman. In 1994, the Council of Ministers headed by Prime Minister Korman passed a resolution to sell all of the government houses and land that had previously belonged to the former Condominium government. These house and land sales were funded through preferential access to loans from the Vanuatu National Provident Fund. ${ }^{20}$

In interviews with the Public Service Commission investigation team, [land] officers pointed out that the decision made by the Hon. Kalsakau was not a new decision. Such [a] decision has already been made in the past by the former Minister for Lands namely Hon. Paul Telukluk and the Former Prime Minister, Maxime Carlot Korman (GoV 2014: 32).

Government officers who administratively supported the Korman government in the illegal registration of state land leases personally benefited. Each of the officers involved was granted a lease over an existing parcel of state land including a government house. While the Ombudsman found that the Korman government leases were illegal in terms of the Constitution and other laws, and involved significant breaches of the leadership code, no members of parliament or government officers were ever prosecuted in relation to these matters. ${ }^{21}$ When asked about their actions in relation to the Kalsakau leases, government officers repeatedly referenced the actions of former government officers who received Korman state land leases, who remain unprosecuted, and who now occupy senior positions in land administration. These references suggest a long-established organisational culture such that government officers have repeatedly supported successive lands ministers in leasing state land and assets.

20 See Public Report on the Improper Sale of Government Houses by the Office of the Prime Minister under the former Prime Minister Maxime Carlot Korman [1998] VUOM 7: 10-11. There are a number of similarities between these Korman government leases and the Kalsakau state land leases. First, the Korman government leases were illegal as they failed to follow proper processes and involved a substantial conflict of interest in which key decision makers personally benefitted from the allocation of public assets. This was confirmed at the time by legal advice provided by the Attorney-General to the Council of Ministers which stated that the sale of land and houses to politicians and their political secretaries without competitive tendering was not in accordance with the leadership code or the law. Second, like the Kalsakau leases, the properties and land were seriously undervalued, and third, while the houses were allocated mainly to politicians and political advisers, key government staff located in the Department of Lands who assisted with the scheme were also allocated houses and state land leases. 21 Public Report on the Improper Sale of Government Houses by the Office of the Prime Minister under the former Prime Minister Maxime Carlot Korman [1998] VUOM 7: 28-33. 
The fragility of governments in Melanesia, and their associated shadow state networks of patronage, also have important implications for the accountability of the bureaucracy. Meeting to respond to Minister Regenvanu's request that they surrender their leases, senior government staff argued in an incendiary fashion that the political cycle was short, that a vote of no confidence would presumably be progressed before any legal action could proceed against them, and that a new government would likely decide not to prosecute staff. These arguments were based on the assumption that a new minister would gain office, supported by investor interests, and would halt any legal action taken against staff. This prediction proved to be correct. On 25 June 2015, newly appointed Minister for Lands Paul Telukluk, well known for previously granting state land to himself, family members and kin, issued an internal memorandum to all Ministry of Lands staff which stated:

My first priority is to deal with the sale of urban land to staff in the Department of Lands. Last Monday, 15 June I asked the DG [DirectorGeneral] and CEO to prepare a COM [Council of Ministers] paper to strike out the court case that the outgoing Minister [Ralph Regenvanu] started against you. My first PA [Principal Advisor] will look over the COM paper to make sure that the government 'cleans the face' of all staff (Telukluk 2015).22

This reference to wanting to 'clean the face' of all staff suggests the deep compact that can exist between government officers and their ministers, such that staff and ministers together engage in leasing state and customary land at heavily discounted rates, rather than acting in the interest of the public. $^{23}$

22 This is a translation of the Bislama version, which reads: '1) Fes priority, hem I sale blo urban land lo staf blo department blo land. Mi askem finis lo DG mo CEO sins las Mandei 15 June 2015 blo preparem wan COM pepa blo strikem kot kase we outgoing minista I mekem agens yufala. 1PA tu bae I lukluk lo COM pepa ia blo mekem soa se bae gavman I klinim fes.'

23 Minister Telukluk also began a media campaign defending the issuing of leases over state land to government officers by his colleague Minister Kalsakau, and attacking the actions of former Minister Regenvanu in challenging the leases and attempting to prosecute staff (Ligo 2015). See also Makin (2015) for Ralph Regenvanu's response to these statements. 


\section{Conclusion: Changing the Rules of the Game}

Questions of legality become confused when land dealings are performed by key state actors and upheld by courts as indefeasible lease titles. Understanding the operation of state power over land in Melanesia involves mapping the terrain of politics, the networks of the shadow state: 'who defines the laws, who implements them, who contests them and why?'(Sundar 2009). Political elites and senior government officers act with the imprimatur of the state, such that their actions are the acts of the state. This is the regulatory basis of the political economy of land dealings in Vanuatu, and elsewhere in Melanesia. Lands ministers and senior government officers should be made accountable for illegal acts by the legal institutions of the state, but their actions are the actions of the state. Who then is able to prosecute the illegal acts?

And how does regulation influence the operation of state power over land? Regulation remains an important element in understanding the way in which state power can be laundered to give effect to land transformations. By carefully studying the processes through which state power is laundered, effective regulation can be designed to alter the capacity of state actors to enact state power through property transactions. In this way, effective land reforms can alter the influence of shadow state networks and change the established norms of behaviour of political elites and government officers.

Recent land reforms in Vanuatu will provide an important case study on whether changing the regulatory rules creates substantial, long-term changes to the exercise of state power over urban and customary land. Led by Minister Regenvanu, and drafted by the author of this chapter, radical land reforms have been enacted that remove the powers of the Minister to act unilaterally in leasing urban and customary land. ${ }^{24}$ Under the new arrangements, the Minister can only lease urban state land on the advice of a committee made up of representatives from government

24 Constitutional amendments and new land laws were debated at length in parliament before being supported by an overwhelming majority of members in December 2013, with the laws coming into effect on 30 February 2014. The land reform package is contained mainly in two pieces of legislation: a new Customary Land Management Act to replace the operation of the existing Customary Land Tribunal Act; and significant amendments to the existing Land Reform Act. As Minister Regenvanu's legal adviser, I was the principal drafter of the land reform package. 
agencies under the authority of an independent chair. ${ }^{25}$ Predictably, the implementation of the new rules has not received the full support of land administration staff.

Vanuatu's land reforms are designed to ensure that state land transactions are in the interests of the public and follow proper legal and administrative processes. These land reforms substantially change the rules of the game relating to land transformations. For instance, if they had been in place at the time that Minister Kalsakau held office, he would not have been able to unilaterally grant urban state land to either government officers or his close family and business associates.

Regulatory reform can influence the political economy of land by changing the rules of the game. Vanuatu's land reforms represent an attempt to wrestle government from the influence of the shadow state. For this reason they remain vulnerable to the haunting presence of the shadow state and its influence over politics. Already Vanuatu's parliamentary opposition is calling for the removal of these reforms. The question that must be asked is: in whose interests do they act?

\section{References}

Borras, S.M. Jr and J.C. Franco, 2010. 'Towards a Broader View of the Politics of Global Land Grab: Rethinking Land Issues, Reframing Resistance.' Rotterdam: Erasmus University, Initiatives in Critical Agrarian Studies (Working Paper 1).

Cotula, L., N. Dyer and S. Vermeulen, 2008. Fuelling Exclusion? The Biofuels Boom and Poor People's Access to Land. London: International Institute for Environment and Development.

Cotula, L., S. Vermeulen, R. Leonard and J. Keeley, 2009. Land Grab or Development Opportunity? Agricultural Investment and International Land Deals in Africa. London: International Institute for Environment and Development.

Deininger, K., 2003. Land Policies for Growth and Poverty Reduction. Washington (DC): World Bank.

25 See Part 6B of the amended Land Reform Act 2015. 
Filer, C., 2011. 'New Land Grab in Papua New Guinea.' Pacific Studies 34: 269-294.

—_, 2012. 'Why Green Grabs Don't Work in Papua New Guinea.' Journal of Peasant Studies 39: 599-617. doi.org/10.1080/03066150. 2012.665891.

Foucault, M., 1991. 'Governmentality.' In M. Foucault, G. Burchell, C. Gordon and P. Miller (eds), The Foucault Effect: Studies in Governmentality. Chicago: University of Chicago Press.

GoV (Government of Vanuatu), 2012. Minutes of the Land Management Planning Committee Meeting, Luganville, 4 October.

——, 2014. Public Service Commission Investigation into Complaints on Corrupt Practices of Lands Officers within the Ministry of Lands. Port Vila: Public Service Commission.

Hall, D., P. Hirsch and T.M. Li, 2011. Powers of Exclusion: Land Dilemmas in Southeast Asia. Singapore: NUS Press.

Kalsakau, S., 2012. 'Allocation of Urban Land to Department of Lands Staff, Both Vila and Luganville.' Letter addressed to the Acting Director of Lands, 3 August.

Li, T.M., 2014. 'What Is Land? Assembling a Resource for Global Investment.' Transactions of the Institute of British Geographers 39: 589-602. doi.org/10.1111/tran.12065.

Ligo, G., 2015. 'Telukluk Outlines Five Lands Ministry Priorities.' Vanuatu Daily Post, 27 June.

Lund, C., 2009. 'Recategorizing "Public" and "Private" Property in Ghana.' In T. Sikor and C. Lund (eds), The Politics of Possession: Property, Authority, and Access to Natural Resources. Chichester: Wiley-Blackwell. doi.org/10.1111/j.1467-7660.2009.01508.x.

Makin, B., 2015 'Response to Article Issued by Telukluk.' Vanuatu Daily Post, 28 July.

McDonnell, S., 2013. 'Exploring the Cultural Power of Land Law in Vanuatu: Law as a Performance That Creates Meaning and Identities.' Intersections 33. 
—_ 2016. My Land My Life: Power, Property and Identity in Land Transformations in Vanuatu. Canberra: The Australian National University ( $\mathrm{PhD}$ thesis).

Peluso, N.L., 2012. 'What's Nature Got to Do with It? A Situated Historical Perspective on Socionatural Commodities.' Development and Change 43: 79-104. doi.org/10.1111/j.1467-7660.2012.01755.x.

Peluso, N.L. and C. Lund, 2011. 'New Frontiers of Land Control: Introduction.' Journal of Peasant Studies 38: 667-681. doi.org/10.108 0/03066150.2011.607692.

Reno, W., 2000. 'Clandestine Economies, Violence and States in Africa.' Journal of International Affairs 53: 433-459.

Rodman, M., 1987. Masters of Tradition: Consequences of Customary Land Tenure in Longana, Vanuatu. Vancouver: University of British Columbia Press.

Scott, J.C., 1998. Seeing Like a State: How Certain Schemes to Improve the Human Condition Have Failed. New Haven (CT): Yale University Press.

Scott, S., M. Stefanova, A. Naupa and K. Vurobaravu, 2012. 'Vanuatu National Leasing Profile: A Preliminary Analysis.' Washington (DC): World Bank, Justice for the Poor Program (Briefing Note 7.1).

Sikor, T., and C. Lund (eds), 2009. 'Introduction.' In T. Sikor and C. Lund (eds), The Politics of Possession: Property, Authority, and Access to Natural Resources. Chichester: Wiley-Blackwell. doi.org/10.1016/j. worlddev.2008.08.010.

Sikor, T and D. Müller, 2009. 'The Limits of State-Led Land Reform: An Introduction.' World Development 37: 1307-1316.

Sundar, N., 2009. Legal Grounds: Natural Resources, Identity, and the Law in Jharkhand. Oxford: Oxford University Press.

Telukluk, P., 2015. 'Internal Memorandum to Lands Department Staff', dated 25 June.

Zoomers, A., 2010. 'Globalisation and the Foreignisation of Space: Seven Processes Driving the Current Global Land Grab.' Journal of Peasant Studies 37: 429-447. doi.org/10.1080/03066151003595325. 
This text is taken from Kastom, property and ideology: Land transformations in Melanesia, edited by Siobhan McDonnell, Matthew Allen and Colin Filer, published 2017 by ANU Press, The Australian National University, Canberra, Australia. 